\title{
Legal Issues of Teleworking
}

\author{
Pavel Sládek ${ }^{1, *}$, Tomáš Sigmund ${ }^{2}$ \\ ${ }^{1}$ Institute of Technology and Business, Faculty of Corporate Strategy, Okružní 517/10, 37001 České Budějovice, Czech Republic \\ ${ }^{2}$ Prague University of Economy and Management, Department of Systems Analysis, W. Churchill Sq 1938-4, Prague 13067 3, \\ Czech Republic
}

\begin{abstract}
Teleworking is a specific type of work where the employee works outside their usual place of work. A characteristic of this activity is the reduction of the need to commute to their employer's workplace and the performance of work during fixed working hours. The following prerequisites are important for real telework: a computer. The worker is in a different place than the employer or the customer. Communication takes place at a distance via telecommunication networks. Instead of a fixed time regime, teleworking allows the employee to individually optimize the performance of their work according to their own needs in terms of time and place (the workplace is most often home). We use the method of identification, analysis, comparison and synthesis of various legal regulations for teleworking all around the world. In teleworking, the powers of the employer and its employees are not equal. That is why it is necessary to create national laws that will better protect the rights of teleworkers.
\end{abstract}

Keywords: teleworking; home office; homeworking; European Framework Agreement on Telework; telecommunication networks

\section{Introduction}

Teleworking (nowadays, the term home office is more commonly used) is a specific style of work that has recently become more and more relevant. The main feature of this activity is the reduction of the need to commute to the employer's workplace and the performance of work during fixed working hours. The advantage of working remotely is the ability of the employee to optimize the performance of their work according to their own needs in terms of time and place. Teleworking has also close links to other modern telecommunications technologies that help its successful implementation. The current dynamic development of telecommunications creates conditions for increasingly simpler and better possibilities of communication with the world from home through various devices, from telephone connections to video conferencing. Managers distinguish between home office and homeworking. Home office is much more common and affects a large number of employees. The employee stays at home, usually due to a child's illness. This way of working is often limited in time. Another option is homeworking - the employee works at home and occasionally commutes to work for better communication and improved social relationships.

\section{Methodology}

We use the method of identification, analysis, comparison and synthesis of various legal regulations for teleworking all around the world. Due to the rapid development and implementation of teleworking, its use among employees is increasing, which creates the necessity for legal regulation. We compared regulations and drew conclusions accordingly.

\section{Results and Discussion}

\subsection{Teleworking in the Czech Republic}

With regards to European legislation on teleworking, the European Framework Agreement on Telework was adopted in 2002. Based on this agreement, individual European countries have developed their own legislation. However, these laws have been interpreted differently in each country [1]. This difference was due to different political interests in each country. The Czech Labour Code 262/2006 [2] regulates the specifics of distance work, but its full implementation is often problematic. The practice of teleworking on the Czech labour market is regulated within the framework of the

\footnotetext{
* Corresponding author: sladek@mail.vstecb.cz
} 
Labour Code, specifically Section 317. The use of this paragraph is possible only if the employee does not work at the employer's workplace and sets the schedule themselves.

\subsection{Teleworking in Slovakia and Poland}

The legislation in neighbouring countries, such as Slovakia and Poland, is more complex. According to Horňák [3], Slovak legislators have succeeded much better in applying European framework agreements on telework to national law. The Slovak provision is marked as $\S 52$ of Act No. 311/2001 Coll. [4], and in many ways reflects our Act 262/2006 Coll. In it, it is explicitly written that if the employer provides the employee with technical equipment, it must take care of that equipment. Paragraphs 3 and 4 also contain a very important provision.

(3) The employer shall take measures which prevent the isolation of an employee working at home (homeworking or teleworking) away from other employees and give them the opportunity to meet other employees.

(4) The employee's working conditions for homeworking and teleworking must not disadvantage the employee in comparison with a comparable employee at the employer's workplace. (Translated by the author) [4]

These provisions are missing in Czech legislation, although according to Horñák [3] they can be deduced from the general provisions of the Labour Code or the Discrimination Act. From the point of view of corporate social responsibility, these issues are very important.

In Poland, Articles $67^{5}$ to $67^{17}$ of the Law of 26 June 1974, Dz.U. 1974 No. 24 item 141, Labour Code [5] regulate teleworking. The mentioned parts of the Code come from the amendment of 24th August 2007 (Dz.U. No. 181 pos. 1288). As Polish trade unions hold a stronger position than Czech trade unions, they also have greater competences in the field of teleworking. According to the Polish provisions, the worker also has better opportunities to negotiate with the employer compared to the situation in the Czech Republic. This is because teleworkers in Poland enjoy greater protection.

A common problem is that employees are forced into teleworking. In Poland, an employee has the option to return to the standard way of working if this remote style of work does not suit them.

Art. $67^{9}$ requires the consent of the employee to change the conditions of work, in the case specified in Art. $67^{7} \S 3$, as well as states that the cessation of work in the form of telework, based on the principles set out in Art. $67^{8}$, may not constitute a reason for justifying the termination of the employment contract by the employer. (Translated by the author) [5]

The employer also has the right to inspect the place where the employee works, even if it concerns the employee's home. However, the employer must have the written consent of the employee to do so and must not infringe on the privacy of the teleworker and their family.

Art. $67^{14}$

$\S 1$. The employer has the right to control the performance of work by the teleworker in their place of work.

$\S 2$. If the work is performed in the teleworker's home, the employer has the right to check:

1) the performance of work;

2) the inventory, and check if the employee maintains, services and/or repairs the entrusted equipment, as well as its installation;

3) occupational safety and health issues - with the prior consent of the teleworker expressed in writing, or by means of electronic communication or similar means of personal remote communication. (Translated by the author) [5]

Like Slovak law, Paragraphs 3 and 4 of the Polish law protects teleworkers against discrimination. The worker must not be discriminated against, for example, in terms of starting and leaving employment, working conditions, promotion and access to training in order to increase professional qualifications compared to other employees employed to carry out the same or similar work.

\subsection{Teleworking in the world}

Despite the rapid development in the field of information and communication technologies, France is not as developed in the field of teleworking as other similarly developed European countries. Therefore, a law supporting teleworking was adopted in 2012 [6]. Despite this law, France faces many problems with this type of work. However, teleworkers are still not as well regarded as traditional workers. French labour law prohibits teleworkers from having employees themselves, with the exception of the help of their spouse, dependent children or support staff.

The employee also has the right to "refuse to take the place of a distance worker and that is not a reason for terminating the employment contract" [7]. 
However, an exception applies here in the case of exceptional circumstances. It is explicitly stated that telework may be ordered without the employee's consent, e.g. in the event of a threat of an epidemic. Within the context of the current quarantine (October 2020), this provision is very topical. Another problem addressed in French law is the obligation to employ the disabled. This is perceived negatively because it leads to greater isolation of the disabled. The same division exists in Quebec law. On the one hand, remote work can be perceived as an adaptation measure, whereas on the other hand, it is important to minimize the risks of isolation.

Another element that hinders the development of teleworking in France is the concept of French management [7], which is considered to be hierarchical and does not adapt to the free organization of the work of the teleworkers towards management, who control this exclusively through well-formulated goals. "The absence of goal-based management, managers' fear of losing power, and the fear of abuse are major obstacles to organization and management." [7] The development of telework is also burdening the legal environment, especially in small and medium-sized enterprises, where there is a risk of litigation because telework is not so often used in the French environment.

In Spain, the status of teleworkers is described in the 2012 law in Article 13 concerning the characteristics of teleworking. This law also addresses the health aspects of employment as well as distance employment. With regards to the ethical aspects of teleworking, in 2017, research was conducted into the gender aspects of telework. The conclusion was that it "perpetuates the asymmetry between the sexes: men in decision-making posts and women as subordinates." [8] These problems also exist in the area of traditional employment.

Another European country that has a law on teleworking is Romania. Act 81/2018 applies to specific professions, such as brokers, sales representatives, analysts, programmers, accountants, financial and tax advisers, translators, etc. [9]. This regulation on teleworking is in line with European legislation, which meets the needs and requirements of the labour market. However, there are certain problems with regards to the issue of occupational safety and health. Other problems are the recording and checking of working hours [10]. According to the current 2020 article on reducing the impact of the crisis in Romania caused by Covid-19, teleworking is popular. This way of working has also become an important motivator for Romanian employees [11]. In order for employees to take full advantage of teleworking, the main precondition is the existence of the law. However, teleworkers feel disadvantaged in the labour market in Romania. Even though lawyers agree that the law is alright [12], the fact is that these workers often receive lower pay, which later disadvantages them with regards to social benefits.

Legislation is being amended around the world. However, in Brazil [13], for example, the benefits of this law are more in its pure existence because it represents progress in recognizing this way of working as a viable way. It is contained in Act 13.467 of 2017, but addresses this issue very little. In Colombia, teleworking has been regulated since 2008 by Act 1221, which, according to the authors, supports job creation and obliges employers to educate employees. [14] Another interesting dimension of this issue is the transnational issue of teleworking. Telework is very often seen as cyberspace or virtual work. This situation enables the application of more than one law in a contract [15]. This option should be avoided in particular by the employee (as the weaker link) because they stand very little chance of winning a dispute. This type of teleworking is characterized by the requirement to have knowledge of foreign languages. [16]

\section{Conclusion}

In teleworking, the powers of the employer and the employee are not equal, which is why some legal regulation is necessary. Teleworking further exacerbates employment inequalities, particularly if the employee is a woman - mother [17]. In Europe, teleworking is regulated quite uniformly because of EU regulations, even though differences between countries exist. In other countries, however, detailed regulation is often lacking, as a result of which workers are often left stranded.

With globalization and the increasing power of international companies, conflicts between various legal systems may arise.

\section{References}

1. A. Belzunegui-Eraso, A. Erro-Garces, Teleworking in the Context of the Covid-19 Crisis. Sustainability. 12(9), $3662(2020)$

2. Czech Republic, Zákoník práce [Labour Code] Zákon [Law] 262/2006 Sb. (2006)

3. L. Hornak, Legal regulation of teleworking in the selected neighboor countries as an inspiration for czech legislation. International Multidisciplinary Conference on the Foreign Impacts on National Law. 50-58 (2014)

4. Czech Republic, Zákonik práce [Labour Code] Zákon [Law] 311/2001 (2001)

5. Poland, Ustawa z dnia 26 czerwca 1974 r. Kodeks pracy [The Act of June 26, 1974, Labor Code]. [online]. Available at: http://isap.sejm.gov.pl/isap.nsf/DocDetails.xsp?id=WDU19740240141 
6. I. Desbarats, Between the protection of workers and the performance of the company: the gestation period of a French right to telework. Cahiers de Droit. 54(2-3), 337-358 (2013)

7. République Francaise, Télétravail [Teleworking] (Articles L1222-9 à L1222-11) [online]. Available at: https://www.legifrance.gouv.fr/

8. A. Galvez, F.Tirado, J. M. Alcaraz, "Oh! Teleworking!" Regimes of engagement and the lived experience of female Spanish teleworkers. Business Ethics-a European Review. 29(1), 180-192 (2019)

9. A. A. Davidescu, A. M. Adriana, S. A. Apostu, Work Flexibility, Job Satisfaction, and Job Performance among Romanian Employees-Implications for Sustainable Human Resource Management. Sustainability. 12(15) (2020)

10. V. Teofila, A. Torres, J. Ignacio, V. Torres, Telework and occupational health: medical-legal and labor aspects. Revista Ces Derecho. 9(2), 287-297 (2018)

11. R. Anderco, Teleworking. 8th International Conference on Perspectives of Business Law in the Third Millennium. 196-202 (2018)

12. M. E. Marica, Hoeworking/teleworking. Atypical forms of employment: between usefulness and precariousness. Juridical Tribune-Tribuna Juridica. 8 (1), 73-85 (2018)

13. B. R. Hazan, P. Morato, A. Duarte, Teleworking in Brazilian Law: Grounds, Perspectives and Changes Promoted by Labor Reform. Lex Humana. 10(1), 1-23 (2018)

14. M.Gutierrez, P. Claudia, R. A.Capone, Socio-economic and legal impact of teleworking in Barranquilla 2014-2015. Justicia. 22(32), 197-213 (2017)

15. D. P. Fincato, M. de Bitencourt, Cyber as Workplace: the Problem (or Solution?) of Transnational Teleworking. Quaestio Iuris. 8(4), 2209-2235 (2015)

16. Z. Caha, The Importance of Corporate Language Education in a Globalised Economy. 32nd Conference of the International-Business-Information-Management-Association (IBIMA). 32 (2018)

17. M. Hilbrecht, S. M. Shaw, L. C. Johnson, J. Andrey, 'I'm home for the kids': Contradictory implications for worklife balance of teleworking mothers. Gender Work and Organization. 15(5), 454-476 (2008) 